Document downloaded from:

http://hdl.handle.net/10251/171214

This paper must be cited as:

Carricondo, JM.; Oliver Villanueva, JV.; Turegano Pastor, JV.; González Romero, JA.; Mengual Cuquerella, J. (2021). Use of Phragmites australis for controlling phospohrus contamination in anthropogenic wetland ecosystems. Environmental Technology. 42(19):3055-3064. https://doi.org/10.1080/09593330.2020.1720311

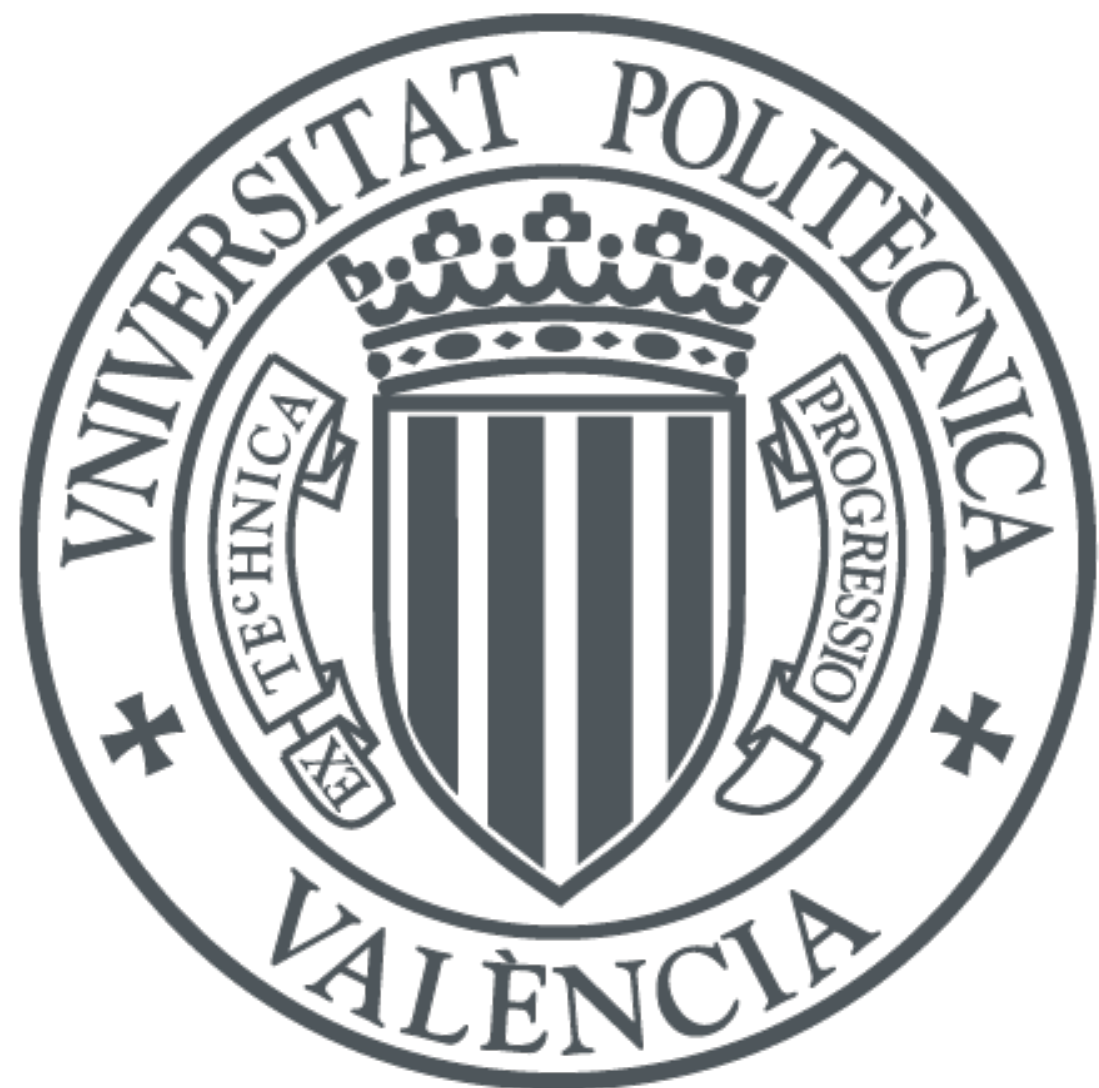

The final publication is available at

https://doi.org/10.1080/09593330.2020.1720311

Copyright Taylor \& Francis

Additional Information

This is an Author's Accepted Manuscript of an article published in J. M. Carricondo, J. V. Oliver-Villanueva, J. V. Turégano, J. A. González \& J. Mengual (2021) Use of Phragmites australis for controlling phosphorus contamination in anthropogenic wetland ecosystems, Environmental Technology, 42:19, 3055-3064, DOI: 10.1080/09593330.2020.1720311 [copyright Taylor \& Francis], available online at:

http://www.tandfonline.com/10.1080/09593330.2020.1720311 


\section{Use of Phragmites australis for controlling phosphorus contamination in anthropogenic wetland ecosystems}

\section{J.M. Carricondo, J.V Oliver-Villanueva, J.V. Turégano, J.A. González \& J. Mengual}

To cite this article: J.M. Carricondo, J.V Oliver-Villanueva, J.V. Turégano, J.A. González \& J. Mengual (2020): Use of Phragmites australis for controlling phosphorus contamination in anthropogenic wetland ecosystems, Environmental Technology, DOI: $\underline{x x x x}$

To link to this article: https://doi.org/xxxxxxxx

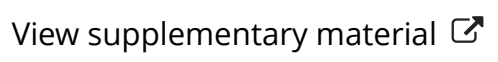

Accepted author version posted online: 27 Jan 2020.

Submit your article to this journal $\sqsubset$

Џll Article views: 2

Q View related articles $\longleftarrow$

View Crossmark data $\nearrow$ 
Publisher: Taylor \& Francis \& Informa UK Limited, trading as Taylor \& Francis Group Journal: Environmental Technology

DOI: $\mathrm{xxxxxx}$

\section{Use of Phragmites australis for controlling phosphorus contamination in anthropogenic wetland ecosystems}

1. Availability of data and material: Datasets on which the conclusions are presented in plots in the main paper and additional document "Appendix A Supplementary Data". For this question we do not wish to share the dates.

2. Competing interests: 'Not applicable'

3. Funding: The first author is a $\mathrm{pH}$ student without funding.

4. Authors' contributions: All authors have contributed to the manuscript under the coordination of the first author, who acts as corresponding author.

5. Acknowledgements: 'Not applicable'

6. Authors' information (optional) 'Not applicable'

\section{J.M. Carricondo ${ }^{\text {a* }}$, J.V Oliver-Villanueva b,c, J.V. Turégano b,c, J.A. González a ,J. Mengual a,d}

a Institute for Water and Environmental Engineering Research - IIAMA, Universitat Politècnica de València, Camino de Vera s/n, Valencia, Spain

$\mathrm{b}$ Department of Rural Engineering - DIRA, Universitat Politècnica de València, Camino de Vera s/n, Valencia, Spain

$\mathrm{c}^{\mathrm{c}}$ Institute for Information and Telecommunication Technologies - ITACA, Universitat Politècnica de València, Camino de Vera s/n, Valencia, Spain

$\mathrm{d}$ Institute of Chemical Technology, Universitat Politècnica de València - Consejo Superior de Investigaciones Científicas, Av. de los Naranjos s/n, Valencia, Spain

\section{*Corresponding author}

\section{Juan Manuel Carricondo}

Institute for Water and Environmental Engineering Research - IIAMA

Universitat Politècnica de València

Camino de Vera s/n, Valencia, Spain

Phone: +34 606190339

J.M. Carricondo: juacaran@upv.es

Prof. Dr. J.V Oliver-Villanueva: joolvil@upv.es

Prof. Dr. J.V. Turégano: jturegan@agf.upv.es

Dr. J.A. González: juagonr1@hma.upv.es

Dr. J. Mengual: jemencu@hma.upv.es 


\section{Abstract}

Continuous phosphorus discharges in bodies of water, generated by human activities such as agriculture, domestic effluences or wastewater from industrial processes, produce contaminated water and eutrophication. For this reason, efficient and low-cost systems that can remove phosphorus from contaminated water are necessary. In addition, it is important to generate renewable energy such as the energy produced in biomass power plants, taking advantage of the available biomass waste in each place. When producing this renewable energy, the resulting ash is a residue that can be used for phosphorus removal by adsorption processes. Moreover, according to the concept of circular economy, the ash waste generated in this bio energy process should be reduced as much as possible. One of the advantages of this research being that surplus phosphorus-laden ash can be reused as fertilizer in agricultural fields. Considering this, the efficiency of reed ash (Phragmites australis) has been analysed in batch experiments, as well as the effect of several parameters on the removal of phosphate such as contact time, phosphate-ash ratio, ash dose and temperature. Significant results obtained show that reed ash can be used to improve water quality.

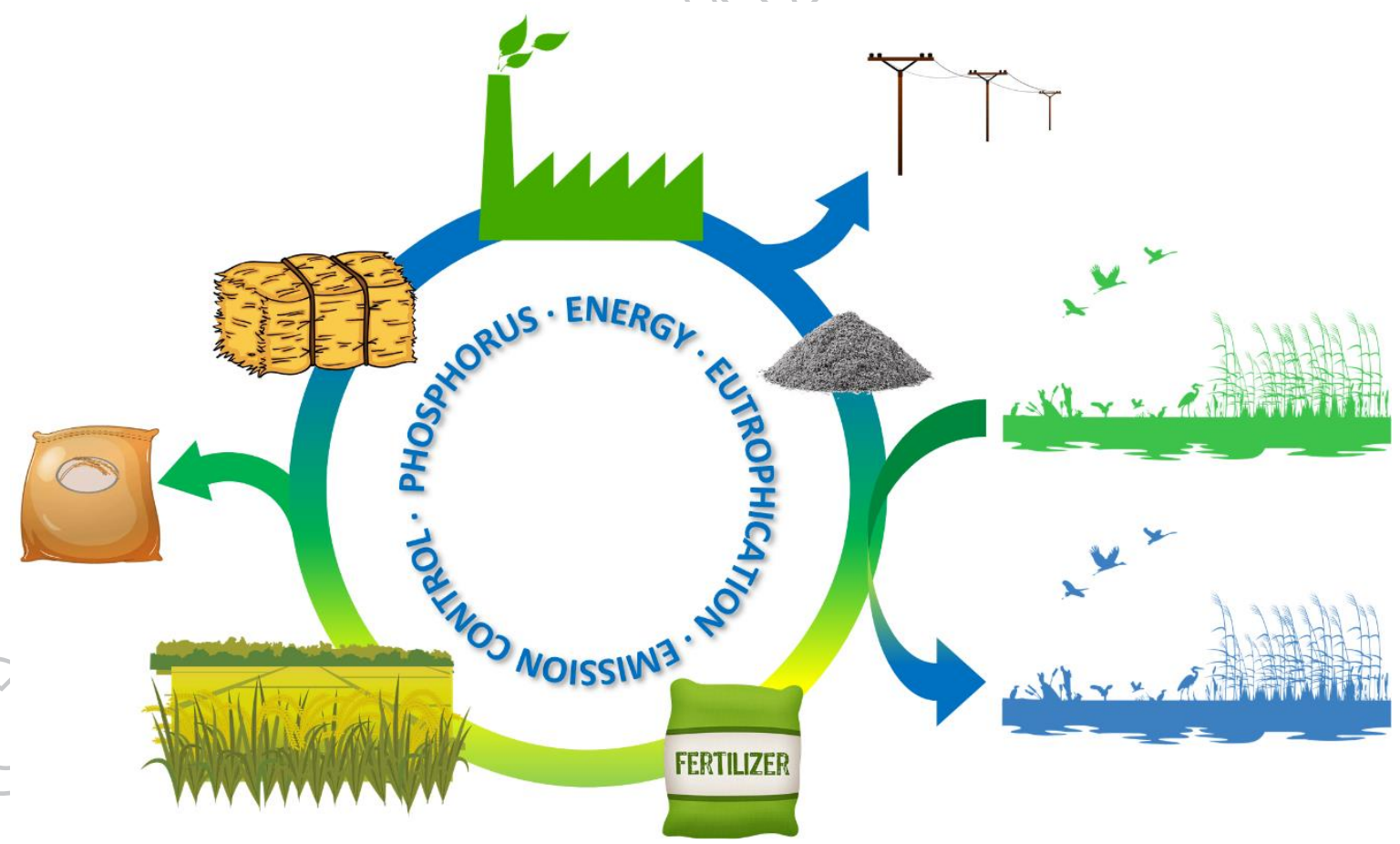

Keywords: Phragmites australis; wastewater; phosphorous adsorption; reed ash; biomass 


\section{Introduction}

Common reed (Phragmites australis (Cav.) Trin. ex Steud.) is an invasive species that commonly forms extensive stands of reed beds around water lagoons and rivers. Common reed is very important for wildlife and conservation, particularly in Europe and Asia, where several species of migratory birds are strongly tied to large reed stands [1,2]. On the other hand, in North America Phragmatites australis is commonly considered an exotic and often-invasive species, introduced from Europe [3]. Moreover, reed has several traditional and cultural uses in agriculture (e.g. baskets) and housing (e.g. thatching roofs) [4].

Reed is one of the main wetland plant species used for phytoremediation water treatment [5]. So, some authors [6] demonstrated that these wetland plants could be used for heavy metal phytoremediation of contaminated agricultural, domestic or even industrial wastewater. Reed has also been used in constructed wetlands, i.e. engineered systems that use the natural functions of vegetation, soil, and organisms to treat agricultural, municipal or industrial wastewater, greywater or stormwater runoff [7]. Similarly to natural wetlands, constructed wetlands also act as biofilters and/or can remove a range of pollutants (such as organic matter, nutrients, pathogens, heavy metals) from the water [8],

Research work shows that increasing nitrogen and phosphorus concentration increases eutrophication in wetlands $[9,10]$. Furthermore, other authors [11] report that by increasing nitrogen and phosphorus concentrations in wetland waters, invasive plants such as Phragmites australis grow faster and form dense thickets of vegetation. So, reed displaces autochthonous plant species such as wild rice, cattails, and native wetland orchids $[12,13]$. Reed has a high above-ground biomass that blocks out light to other plants [14], allowing areas to turn into monoculture very quickly [15].

Anthropogenic wetlands combine natural vegetation with agricultural crops, especially rice plantations [16,17]. Research work [18] analysed essential and non-essential/toxic elements in 86 rice types produced in wetlands all around the world. The obtained average content of the essential elements are: $1,189 \mathrm{mg} \mathrm{kg}^{-1}(\mathrm{P}), 746 \mathrm{mg} \mathrm{kg}^{-1} \quad(\mathrm{~K}), 294 \mathrm{mg} \mathrm{kg}^{-1}$ $(\mathrm{Mg}), 84.7 \mathrm{mg} \mathrm{kg}^{-1}$ (Ca), $13.3 \mathrm{mg} \mathrm{kg}^{-1}(\mathrm{Zn}), 8.8 \mathrm{mg} \mathrm{kg}^{-1}(\mathrm{Na}), 8.3 \mathrm{mg} \mathrm{kg}^{-1}(\mathrm{Mn}), 7.5 \mathrm{mg} \mathrm{kg}-$ ${ }^{1}(\mathrm{Fe}), 1.9 \mathrm{mg} \mathrm{kg}^{-1}(\mathrm{Cu}), 0.55 \mathrm{mg} \mathrm{kg}^{-1}$ (Mo), $0.18 \mathrm{mg} \mathrm{kg}^{-1}$ (Se) and $0.12 \mathrm{mg} \mathrm{kg}^{-1}$ (Co). These elements are present in the rice fields, so that the plants can feed on them; NPK being the 
most necessary nutrients [19]. Phosphorus inputs are produced in these wetlands due to agricultural fertilizers and wastewater discharges that do not have phosphorus elimination or filtering systems [20-23].

Furthermore, other studies show how the reed growth influences directly the concentration decrease of macronutrients such as phosphorus [11] as well as heavy metals $[24,25]$. Therefore, pruning reed in wetlands can be considered a good environmental practice since macronutrients such as $\mathrm{N}$ and $\mathrm{P}$ are extracted from the water, taking into account that a high concentration of these elements generates eutrophication [26].

The decrease of chemical elements concentrated in water by the absorption of reed does not occur equally over the life of the plant [27]. So, the growing regime determines the nutrients absorption. There is a linear relationship between reed biomass growth and $\mathrm{N}$ and $\mathrm{P}$ abstraction [28]. This annual growth depends on the type of wetland, from $32 \mathrm{Tn} \mathrm{ha}^{-1} \mathrm{year}^{-}$ ${ }^{1}$ in natural wetlands to $70 \mathrm{Tn} \mathrm{ha}^{-1} \mathrm{year}^{-1}$ in infiltration wetlands [28].

The best harvesting time of reed biomass is determined by the flowering. Reed has to be pruned before the seeds are released at the moment of maximum biomass and higher nutrients concentration ( $\mathrm{N}$ and $\mathrm{P}$ ). So, the parts of the plants in senescence neither detach from the plant nor return the nutrients to the water, avoiding problems of eutrophication [28].

The pruning process of reed in the wetlands generates residual biomass that can be used for bioenergy generation in biomass plants [29,30]. Reed ash is generated as waste in the industrial combustion process. One interesting alternative solution for an effective waste management is to reincorporate this ash into the rice plantations, with the principal aim of removing phosphorus, but also taking advantage of the capacity of reed to adsorb heavy metals [31] existing in wetland lagoons like $\mathrm{Zn}, \mathrm{Cu}, \mathrm{Ni}$ and $\mathrm{Pb}$ [32]. This opportunity for waste valorisation is also based on the experiences described by other authors [33,34], who demonstrate the capacity of other plant ashes for the elimination of phosphorus in contaminated waters.

Thus, the main objective of this research is to analyse the feasibility of using common reed (Phragmites australis) for controlling phosphorus contamination in anthropogenic wetland ecosystems. To achieve this objective, the research focuses on the use of the reed ash, generated in bioenergy plants, in the removal of phosphate from contaminated water in the same wetland where reed is growing. To do this, batch-type 
experiments were developed to analyse the effect of several parameters on phosphorus removal. These parameters are mainly contact time, phosphorus-ash ratio, ash dose and temperature. Furthermore, the research aims to assess the viability of using ashes from other plant materials produced by wetland agriculture (specifically rice straw ash) to complement the obtained reed ash in order to eliminate phosphorus. Finally, following the experiences of other authors with other plant ashes [35,36], the research also analyses the subsequent utilization of reed ash, after phosphorus removal, as natural fertilizer in wetland rice plantations, closing the circular economy system [37]. 


\section{Materials and methods}

\subsection{Preparation of testing material}

Reed samples for the experiments were obtained from the L'Albufera wetland located 10 kilometres south of Valencia (Spain). It is a freshwater lagoon and estuary on the Gulf of Valencia coast, in eastern Spain. It represents the main portion of the Valencian Albufera Natural Park, with a surface area of 21,120 hectares. The natural biodiversity found here allows for a great variety of flora and fauna all year-round. Though once a saltwater lagoon, dilution due to irrigation and canals draining into the estuary, as well as sand bars increasing in size, had converted it to freshwater by the 17 th century. Rice growing has been the most important traditional use of this land since the 18th century. It has great environmental importance, apart from the economic, because plant and animal species that have disappeared from the lake itself still live in the surrounding rice fields, where the water of the lagoon is purified. These rice paddies also provide food and shelter for many birds. L'Albufera is a complex anthropogenic wetland ecosystem and is included on the Convention on Wetlands of International Importance(RAMSAR list).

The aquatic vegetation occupies 300 hectares around the lagoon. It is formed by submerged, floating and marshy communities, which have great biodiversity and singular importance. This vegetation inhabits flooded areas during a great part of the year, although also permanent waters, with the roots inside the water and the stem and the leaves emerged. The main species is reed (Phragmites australis), accompanied by other aquatic species such as Scirpus lacustris, Typha latifolia, Cladium mariscus and Kosteletzkya pentacarpos.

The testing material was obtained from the pruning of a mature stand of reed in the area of El Palmar (Geographical coordinates: 39,315676085065256, 0,3197024279343168). $20 \mathrm{Kg}$ of reed biomass were harvested and transported to the bioenergy plant located in Ademuz, Valencia, Spain. After the combustion process, $1.518 \mathrm{Kg}$ of reed ash was transported to the lab for the tests. 


\subsection{Preparation and characterization of adsorbents}

The reed ash (RA) was heated at $778 \mathrm{~K}$ for $1 \mathrm{~h}$ in a muffle furnace, loosing $20-22 \%$ of total weight. Thereafter, RA was washed with distilled water until the conductivity was under $1000 \mu \mathrm{S} \mathrm{cm}^{-1}$. Next, RA was dried at $378 \mathrm{~K} 24 \mathrm{~h}$ in an oven to achieve constant weight. Finally, following the recommendations of other authors [38] RA was sieved with a $1 \mathrm{~mm}$ grid sieve to ensure uniform particle size for the lab tests.

Characterization of adsorbents was done using different techniques. To determine the major and trace elements present in the adsorbent, chemical analyses were carried out in an optical emission spectrometer (Varian 715-ES ICP), after dissolution in $\mathrm{HNO}_{3} / \mathrm{HCl} / \mathrm{HF}$. Elemental RA analysis $(\mathrm{C}, \mathrm{H}, \mathrm{N}, \mathrm{S})$ was performed on a thermo-organic element analyser Fisons EA 1108 CHNS-O. To know the crystalline nature of the material, powder X-ray diffraction (PXRD) measurements were performed with a multisample Philips X'Pert diffractometer, equipped with a graphite monochromator, operating at $40 \mathrm{kV}$ and $35 \mathrm{~mA}$, and using $\mathrm{Cu} \mathrm{K \alpha}$ radiation $(\lambda=0,1542 \mathrm{~nm})$. The particle morphology of the samples was studied by field emission scanning electron microscopy (FESEM), using a ZEISS Ultra5-55 microscope. Additionally, textural properties were determined by $\mathrm{N} 2$ adsorption-desorption isotherms measured on a Micromeritics ASAP 2020 at $77 \mathrm{~K}$. The $\mathrm{pH}$ and electrical conductivity measurements of RA were carried out on a pH meter and conductometer MULTI 340i. Following other laboratory experiences [39], $\mathrm{pH}$ and electrical conductivity of RA were measured after stirring distilled water with raw ash with a ratio of $1 / 10(\mathrm{~V} / \mathrm{W})$ for 10 minutes.

\subsection{Adsorption isotherms and kinetics}

In order to determine the adsorption capacity of RA, adsorption isotherm experiments were conducted varying contact time from 0 to $120 \mathrm{~h}$ with initial phosphorus concentration of $80 \mathrm{ppm}$ at different temperatures (283, 293 and $303 \mathrm{~K})$, following the recommendations of other authors [40,41]. Adsorption isotherms show the relation between the total mass adsorbed per gram of adsorbent, qe $\left(\mathrm{mg} \mathrm{g}^{-1}\right)$, and the equilibrium concentration of adsorbate, $\mathrm{Ce}\left(\mathrm{mg} \mathrm{L}^{-1}\right)$, at constant temperature and $\mathrm{pH}$ [42]. Three adsorption isotherm models have been applied for the lab experiments: Langmuir [43], Freundlich [44] and Temkin [45]. 
The Langmuir adsorption model [43] is given below:

$$
q_{e}=\frac{q_{\max } K_{L} C_{e}}{1+K_{L} C_{e}}
$$

where $q_{\mathrm{e}}$ is the amount of sorbate at time and equilibrium $\left(\mathrm{mg} \mathrm{g}^{-1}\right), C_{e}$ is the equilibrium concentration of the remaining solute in the solution $\left(\mathrm{mg} \mathrm{L}^{-1}\right), q_{\max }$ is the amount of adsorbate per mass unit of adsorbent at complete monolayer coverage $\left(\mathrm{mg} \mathrm{g}^{-1}\right)$, and $\mathrm{K}_{\mathrm{L}}$ is the Langmuir equilibrium constant relating to the strength of adsorption $\left(\mathrm{L} \mathrm{mg}^{-1}\right)$.

The Freundlich adsorption model [44] is given below:

$$
q_{e}=K_{L} C_{e}^{\frac{1}{n}}
$$

where $q_{\mathrm{e}}$ is the amount of sorbate at time and equilibrium $\left(\mathrm{mg} \mathrm{g}^{-1}\right), C_{e}$ is the equilibrium concentration of the remaining solute in the solution $\left(\mathrm{mg} \mathrm{L}^{-1}\right), n$ and $K_{L}$ is the Freundlich equilibrium constant.

The Temkin adsorption model [45] is given below:

$$
q_{e}=B \ln \left(\begin{array}{ll}
K_{T} & C_{e}
\end{array}\right)
$$

where $q_{e}$ is the amount of sorbate at time and equilibrium $\left(\mathrm{mg} \mathrm{g}^{-1}\right), K_{T}\left(\mathrm{~L} \mathrm{mg}^{-1}\right)$ is the Temkin equilibrium constant, $B\left(\mathrm{mg} \mathrm{g}^{-1}\right)$ is related with the variation of adsorption energy and $C_{e}$ is the equilibrium concentration of the remaining solute in the solution $\left(\mathrm{mg} \mathrm{L}^{-1}\right)$.

When isotherm arrived at equilibration after three days (72 h), the solution was filtered through a Prat Dumas glass microfiber filter $(25 \mathrm{~mm}$ and retention micrometry 1,2 $\mu \mathrm{m}$ ) in order to separate the solid from liquid phase. So, the liquids were collected in clean vials. The phosphorus concentration was determined using a chromatograph Spectroquant NOVA 60. 


\subsection{Batch adsorption experiments}

Following other documented experiences $[39,46]$, adsorption experiments were carried out in batch mode by using different concentrations of $\mathrm{Na}_{2} \mathrm{HPO}_{4}$ on $50 \mathrm{ml}$ of synthetic waste-water in $100 \mathrm{ml}$ of conical flask and then stirred at different temperatures $(283,293$ and $303 \mathrm{~K})$.

Phosphorus stock solution ( $80 \mathrm{~g} \mathrm{~L}^{-1}$ ) was prepared by dissolving $0.3704 \mathrm{~g} \mathrm{Na}_{2} \mathrm{HPO}_{4}$ in 1 liter of distilled water. Further serial dilutions were made to have synthetic wastewater of desired phosphorus concentrations $(2.5,5,10,15,20,25,30,40,50,60$, 70 and $\left.80 \mathrm{~g} \mathrm{~L}^{-1}\right)$.

RA adsorption tests were carried out with doses of $0.5 \mathrm{~g} \mathrm{~L}^{-1}, 1.5 \mathrm{~g} \mathrm{~L}^{-1}, 2.5 \mathrm{~g} \mathrm{~L}^{-1}$, and $5 \mathrm{~g} \mathrm{~L}^{-1}$ with a total contact time of $72 \mathrm{~h}$ (Figure 1 ).

\section{... Figure 1 about here...}

After adsorption, the solution was filtered through the Prat Dumas glass microfiber filter $(25 \mathrm{~mm}$ and retention micrometry $1,2 \mu \mathrm{m})$. The phosphate concentration was determined using a chromatograph Spectroquant NOVA 60.

The percentage of phosphorus removal (see Appendix A - Supplementary Data), or removal efficiency, was calculated by using the formula given below:

$$
\% \text { Removal efficiency }=\frac{C_{o-C_{F}}}{C_{o}} \times 100
$$

where $C_{\rho}$ is the initial phosphorus concentration $\left(\mathrm{mg} \mathrm{L}^{-1}\right)$ and $C_{F}$ is the final phosphorus concentration $\left(\mathrm{mg} \mathrm{L}^{-1}\right)$. 


\section{Results and discussion}

\subsection{Physical and chemical characteristics of the adsorbent}

The physical and chemical properties of RA are summarized in Table 1 . The main component in the adsorbent is silicon oxide with a low concentration of other metal oxides such as iron, aluminium, copper or zinc. However, the amount of alkaline and alkaline-earth metal oxides is very high ( $\mathrm{Ca}$ and $\mathrm{K}$ mainly), approaching that of the silica.

\section{... Table 1 about here...}

The adsorbent has a basic buffer capacity, increasing the pH of water to a value around 10 (see Figure 8). This is due to a high presence of alkaline-earth metal oxides in its composition.

The adsorbent has a high percentage of external surface area, showing that it is not a micro porous material. Hence, it is expected that most of the adsorbent process will take place in that external surface.

\section{Figure 2 about here...}

A scanning electron micrograph (SEM) of the adsorbent (Figure 2) shows a noncrystalline heterogenic distribution of particles in RA; the morphology of the RA indicates the presence of porous and rough surfaces, with different shapes and sizes, in the range from few to a several hundred micrometers.

\subsection{Effect of adsorbent dose}

The removal of phosphorus was carried out using synthetic wastewater containing $2.5,5,10,15,20,25,30,40,50,60,70$ and $80 \mathrm{~g} \mathrm{~L}^{-1}$ of phosphorus. 110,130 and 150 $\mathrm{g} \mathrm{L}^{-1}$ of phosphorus were added to an initial solution of RA-water of $5 \mathrm{~g} \mathrm{~L}^{-1}$ at $293 \mathrm{~K}$ temperature. Adsorption isotherm experiments were conducted during a total contact time of $72 \mathrm{~h}$. The results show that the efficiency $\left(\mathrm{mg} \mathrm{g}^{-1}\right.$ of $\left.\mathrm{P}\right)$ increases when the contact time between the adsorbent and phosphorus increases, until reaching equilibrium after 48 to 72 hours, as can be seen in Figure 3. This coincides with other experiences [7]. 
Adsorption studies of RA were carried out with different doses: $0.5 \mathrm{~g} \mathrm{~L}^{-1}, 1.5 \mathrm{~g} \mathrm{~L}^{-1}$, $2.5 \mathrm{~g} \mathrm{~L}^{-1}$ and $5 \mathrm{~g} \mathrm{~L}^{-1}$. For RA the percentage of phosphorus removal varies with the phosphorus-ash ratio $(68.0-98.3 \%)$. The maximum adsorption $(98.3 \%)$ is shown by a concentration at $5 \mathrm{~g} \mathrm{~L}^{-1}$ at $293 \mathrm{~K}$. This concentration shows also a high capacity for phosphorus removal (29.3 $\mathrm{mg} \mathrm{P} \mathrm{g}^{-1}$ ), as can be observed in Figure 4.

\section{... Figure 4 about here...}

Ion exchange processes can be observed during phosphate adsorption. Water conductivity varies in the range between 286 and $1,120 \mu \mathrm{S} \mathrm{cm}^{-1}$ and increases with ash concentration and phosphorus-ash ratio. Thus, the results obtained demonstrate that the phosphorus removal capacity of RA clearly increases when the adsorbent dose increases. This observed relationship coincides with the results of other authors with other plant ashes [47].

With the increasing amount of RA as adsorbent, the decreasing of adsorption capacity was due to the increasing interface area when the suspension was diluted. On the other hand, for the phosphorus adsorption, more ions were into the adsorbent by way of swelling and water absorption by the RA. $[48,49]$.

\subsection{Influence of temperature on the phosphate removal process}

The analysis of the influence of temperature was studied by putting the adsorbent in contact with the phosphorus until reaching equilibrium. This occurs after three days, after which constant values remain. The phosphorus removal was carried out using synthetic wastewater containing different phosphorus concentrations. The experiments were carried out at different temperatures $(283,293$ and $303 \mathrm{~K})$ with $1.5 \mathrm{~g} \mathrm{~L}^{-1}$ of RA adsorbent, as shown in Figure 5.

\section{... Figure 5 about here...}

Following the Langmuir adsorption model, Figure 6 shows that $\mathrm{q}_{\max }$ increases when the temperature increases from $283 \mathrm{~K}\left(18.22 \mathrm{mg} \mathrm{P} \mathrm{g}^{-1}\right)$ to $293 \mathrm{~K}\left(23.15 \mathrm{mg} \mathrm{P} \mathrm{g}^{-1}\right)$. Nevertheless, $\mathrm{q}_{\max }$ decreases when the temperature increases from $293 \mathrm{~K}$ (23.15 mg P $\left.\mathrm{g}^{-1}\right)$ to $303 \mathrm{~K}\left(21.27 \mathrm{mg} \mathrm{P} \mathrm{g}^{-1}\right)$. 
The effect of adsorption occurs when the value of the isosteric enthalpy is positive. The results between the temperature of $283 \mathrm{~K}\left(-2.23 \mathrm{~kJ} \mathrm{~mol}^{-1}\right)$ and $293 \mathrm{~K}\left(-1.27 \mathrm{~kJ} \mathrm{~mol}^{-}\right.$ ${ }^{1}$ ) indicate that the reaction is exothermic. So, when the reaction is exothermic the adsorption increases. On the other hand, the adsorption process decreases from $293 \mathrm{~K}$ to $303 \mathrm{~K}\left(1.07 \mathrm{~kJ} \mathrm{~mol}^{-1}\right)$. This indicates a negative isosteric enthalpy of adsorption and an endothermic reaction.

Temperature influences significantly the phosphorus removal capacity of RA. Hence, RA with a concentration at $1.5 \mathrm{~g} \mathrm{~L}^{-1}$ and a temperature of $303 \mathrm{~K}$ achieves a maximum adsorption of $97.3 \%$. By contrast, the highest capacity for phosphorus removal $\left(23.15 \mathrm{mg} \mathrm{P} \mathrm{g}^{-1}\right)$ has been observed with a concentration at $1.5 \mathrm{~g} \mathrm{~L}^{-1}$ at $293 \mathrm{~K}$, as shown in table 2 .

\section{...Table 2 about here...}

The Langmuir adsorption model was originally applied to the adsorption of gases on a solid surface and, subsequently, to a liquid phase [43]. The dynamic adsorption equilibrium is related to the rate constants of adsorption and desorption. At equilibrium there is no net change, the sum of these two rates is zero, and the equilibrium constant (i.e., ratio between adsorption and desorption rate constants) is $K_{L}$. Taking this into account, $K_{L}$ is essentially an equilibrium constant of the overall process, which takes place during phosphorus adsorption. Furthermore, its temperature dependence can be used to determine the isosteric enthalpy of adsorption $\left(\Delta_{\mathrm{ad}} H^{\circ}\right)$ using the Van't Hoff equation:

$$
\left(\frac{\partial \ln K}{\partial(1 / T)}\right)_{\theta}=-\frac{\Delta_{a d} H^{\circ}}{R}
$$

Figure 6 shows the graphical representation of the Van't Hoff equation of the experimental data. The slope of each curve represents the isosteric enthalpy of adsorption for each adsorbent. A clear linearity of the curves can be observed, as confirmed by the high values of the coefficients of determination $\left(\mathrm{R}^{2}>0.9\right)$. 
The calculated enthalpy value of RA is $48.79 \mathrm{~kJ} \mathrm{~mol}^{-1}$. The positive value indicates the endothermic nature of the total process, which takes place during the phosphorus adsorption.

\subsection{Influence of $\mathrm{pH}$ on the phosphorus removal process}

Different authors studied the influence of the $\mathrm{pH}$ on the adsorption capacity of ashes, regulating the $\mathrm{pH}$ by means of $0.1 \mathrm{M} \mathrm{HCl}$ and $0.1 \mathrm{M} \mathrm{NaOH}[38,50]$. These authors demonstrate that the adsorption increases when the $\mathrm{pH}$ decreases. However, other authors conclude for rice husk that a reduction in $\mathrm{pH}$ also reduces the absorption capacity [35]. Furthermore, other research studies reach the final maximum level of absorption capacity around a neutral $\mathrm{pH}$ in the case of rice husk and fruit residues [51]. Consequently, the reference literature shows very different results regarding the influence of $\mathrm{pH}$ on the phosphorus absorption capacity by plant ashes.

In the present research, the relation between $\mathrm{pH}_{\text {initial }}$ and $\mathrm{pH}_{\text {final }}$ is established. This has been done adjusting the initial $\mathrm{pH}$ values with $0.1 \mathrm{M} \mathrm{HCl}$ and $0.1 \mathrm{M} \mathrm{NaOH}$ and adding $1.5 \mathrm{~g} \mathrm{~L}^{-1}$ of RA to the aqueous solution. The mixture is stirred until the $\mathrm{pH}$ stabilizes. So, $\mathrm{pH}$ value is known, as can be observed in Figure 8.

... Figure 8 about here...

Figure 8 shows the buffer effect of $\mathrm{RA}$, achieving a $\mathrm{pH}_{\text {final }}=9.61$ with $\mathrm{pH}_{\text {initial }}=3$ and $\mathrm{pH}_{\text {final }}=10.53$ with $\mathrm{pH}_{\text {initial }}=10$.

\subsection{Influence of ionic strength and Ca cations on the phosphate removal process}

Figure 9 represents the influence of ionic strength on RA adsorption capacity. The experiments were carried out at $293 \mathrm{~K}$, with a constant adsorbent dose of $10.5 \mathrm{~g} \mathrm{~L}^{-1}$ and different concentrations of phosphorus in the water solution (10 to $80 \mathrm{mg} \mathrm{P} \mathrm{L}^{-1}$ ). The figure allows comparing the behaviour of the original sample (with an average conductivity of 594 $\mu \mathrm{S} \mathrm{cm}$ ) with an alternative test with a controlled ionic strength of $2.0 \mathrm{mS} \mathrm{cm}^{-1}$ using the necessary concentration of $\mathrm{NaCl}$. As can be observed, the presence of sodium and chloride ions results in a higher ionic strength. This higher ionic strength has a slight positive effect on phosphorus adsorption capacity. Therefore, the presence of chloride ions does not have negative effect on the adsorption capacity, in line with the conclusions of other authors [20]. 
The adsorption increase in the presence of sodium and chlorine ions observed in RA can be due to the impediment that supposes a greater ionic strength in the process of exchange / dissolution of ions between the solution and the adsorbent [52]. This impediment would reduce the presence of other competitive ions of the adsorbent itself in favour of noncompetitive chlorine ions.

Following the experiences of other authors [34,41,53,54], it can be stated that the elimination of phosphorus depends on the dissolution of $\mathrm{Ca}$ ions in the adsorbent. These authors also show that the fixing of phosphorus is mainly carried out by these cations in aqueous solutions with ash. Therefore, for RA it is expected that the higher the Ca content, the greater the phosphorus removal capacity, as observed. To verify the substantive role played by the presence of $\mathrm{Ca}$ ions in the solution, the experiments were performed using two different $\mathrm{Ca}$ concentrations of $\mathrm{CaCl}_{2} \cdot 4 \mathrm{H}_{2} \mathrm{O}\left(10 \mathrm{mg} \mathrm{L}^{-1}\right.$ and $\left.40 \mathrm{mg} \mathrm{L}^{-1}\right)$. The tests were performed with a controlled ionic strength of around $2.0 \mathrm{mS} \mathrm{cm}^{-1}$ at $293 \mathrm{~K}$, an adsorbent dose of $1.5 \mathrm{~g} \mathrm{~L}^{-1}$ and different concentrations of phosphorus in water (from 10 to $80 \mathrm{mg} \mathrm{P}$ $\left.\mathrm{L}^{-1}\right)$. Figure 9 shows the results for both $\mathrm{Ca}$ concentrations. The presence of $\mathrm{Ca}$ in the solution has a positive effect on the capacity of phosphorus adsorption, increasing the capacity as the concentration of Ca increases. These results clearly confirm the determining influence of the Ca cation in the phosphorus removal process.

\subsection{Combined use of reed ash and rice straw ash for phosphorus removal and use as natural fertilizer}

Ashes from other plant materials produced by agriculture in the wetlands (specifically rice straw ash RSA) can complement the obtained RA in the removal of phosphorus. Different authors have analysed $[33,48,55]$ the adsorption capacity of other agricultural waste produced in wetland agriculture, like rice husk, fruit juice residues and wheat straw. Taking into account that rice is the most extended agricultural crop in wetlands worldwide, a combined use of RA and RSA as a natural phosphorus filter can be an interesting alternative, leading to a revaluation of these residues [56,57].

In order to compare with the previous results, the experiments have been conducted with a constant ash concentration of $5 \mathrm{~g} \mathrm{~L}^{-1}$ in the aqueous solution and a constant temperature of $293 \mathrm{~K}$. Furthermore, to compare different ash mixtures, the following 
ratios between RA and RSA have been tested: 5:0, 4:1, 3:2, 2:3, 1:4, 0:5. The phosphorus concentrations are 5,10, 20, 40, 60 and $80 \mathrm{mg} \mathrm{L}^{-1}$. An additional test has been conducted with $110 \mathrm{~g} \mathrm{~L}^{-1}$ of phosphorus concentration for the mixture RA and RSA 5:0.

\section{... Figure 10 about here...}

Figure 10 shows the obtained results of these experiments. The curves obtained for the different RA and RSA ash mixtures show that the phosphate adsorption is proportional to the amounts of adsorbents in the different mixtures.

For the same amount of initial phosphorus in the aqueous solution, a linear function is generated with which the intermediate points that are between the pure concentrations of each adsorbent can be calculated. This function is given by the equation:

$$
q_{e}=\frac{\left[P_{o}\right]}{A}-\frac{V \times C_{e}}{A}
$$

Where $q_{\mathrm{e}}$ is the amount of sorbate at time and equilibrium $\left(\mathrm{mg} \mathrm{g}^{-1}\right), \mathrm{L}$ is volume (L), A is the amount of total ash mixed $(\mathrm{g}), C_{e}$ is the equilibrium concentration $\left(\mathrm{mg} \mathrm{L}^{-1}\right)$ and $\mathrm{P}_{\mathrm{o}}$ is the initial amount of phosphorus $\left(\mathrm{mg} \mathrm{L}^{-1}\right)$.

Supplies of rice straw and reed straw are readily available; different studies recommend the use of rice straw and reed straw as biomass for producing energy in biomass plants $[29,58]$. The results of another study concludes that crop biomass ash can be an adequate phosphorus source comparable to that of highly soluble commercial phosphorus fertilizer [59]. In addition, it has been shown that different crop biomass ashes, i.e. rape meal ash, straw ash, and cereal ash, could be used as fertilizer. While other studies show the capacity of adsorption of cereal straw [38] and the adsorption of heavy metals or dyes of reed straw [60].

Rice fields and wetlands generate a significant amount of non-agricultural biomass, reed straw generally, and considering that in different places there are different proportions of rice straw waste and non-agricultural biomass production, therefore, the use of mixtures of rice and reed straw was studied. The proportions of the mixtures depends on the availability of reed and rice ashes, the initial phosphorus concentration and the final phosphorus concentration in the water. In the case of rice and reed, the higher the amount of reed ash the greater the adsorption capacity. 


\section{Conclusions}

Reed is a natural biomass which is available in large quantities and can be used to produce energy in biomass power plants. These companies generate a waste called reed ash, which can be used to remove phosphorus from contaminated water. The results of this study demonstrate the adsorption capacity of phosphorus and show that the maximum adsorption capacity is up to $98.3 \%$, in a concentration at $5 \mathrm{~g} \mathrm{~L}^{-1}$ at $293 \mathrm{~K}$. This concentration also shows a high capacity for phosphorus removal ( $\mathrm{q}_{\max } 29.3 \mathrm{mg} \mathrm{P}$ $\left.\mathrm{g}^{-1}\right)$. The Langmuir isotherms model depicts the best fits to the experimental data with correlation coefficients greater than 0.95 . The adsorption of phosphorus ions in the RA adsorbent is a rapid process, less than 72 hours. SEM of the adsorbent shows noncrystalline particles and the morphology of RA indicates the presence of a porous and rough surface. The results of the study indicate that the RA could be used as a low-cost adsorbent for the treatment of water and wastewater treatment.

\section{References:}

[1] Rodrigo MA, Valentín A, Claros J, et al. Assessing the effect of emergent vegetation in a surface-flow constructed wetland on eutrophication reversion and biodiversity enhancement. Ecol Eng 2018;113:74-87.

[2] Fasola M, Ruiz X. The Value of Rice Fields as Substitutes for Natural Wetlands for Waterbirds in the Mediterranean Region. Colon Waterbirds 1996;19:122.

[3] Saltonstall K. Invasion by a non-native genotype of the common reed, Phragmites australis, into North America. Proc Natl Acad Sci 2002;99:2445-9.

[4] Hulshof M, Vos J. Diverging realities: how framing, values and water management are interwoven in the Albufera de Valencia wetland in Spain. Water Int 2016;41:107-24.

[5] Ahmad S., Reshi Z., Shah M., et al. Phytoremediation Potential of Phragmites australis in Hokersar Wetland - A Ramsar Site of Kashmir Himalayanternatio. Ina J Phytoremediation 2014;16:12:1183-91.

[6] Chandra R, Yadav S. Phytoremediation of $\mathrm{Cd}, \mathrm{Cr}, \mathrm{Cu}, \mathrm{Mu}, \mathrm{Fe}, \mathrm{Ni}, \mathrm{Pb}$ and $\mathrm{Zn}$ from Aqueous Solution Using Phragmites Cummunis, Typha Angustifolia and Cyperus Esculentus. Int J Phytoremediation 2011;13:6:580-91.

[7] Hoffmann H, Platzer C, von Münch E, et al. Technology review of constructed wetlands - Subsurface flow constructed wetlands for greywater and domestic wastewater treatment. Dtsch Gesellschaft Für Int Zusammenarbeit GmbH, 
Eschborn, Ger 2011.

[8] Brix H, H Schierup H, Arias C. Twenty years experience with constructed wetland systems in Denmark - What did we learn? Water Sci Technol 2007;56:63-8.

[9] Vybernaite-Lubiene I, Zilius M, Giordani G, et al. Effect of algal blooms on retention of N, Si and P in Europe's largest coastal lagoon. Estuar Coast Shelf Sci 2017;194:217-28.

[10] del Barrio Fernández P, Gómez AG, Alba JG, et al. A model for describing the eutrophication in a heavily regulated coastal lagoon. Application to the Albufera of Valencia (Spain). J Environ Manage 2012;112:340-52.

[11] Uddin MN, Robinson RW. Can nutrient enrichment influence the invasion of Phragmites australis? Sci Total Environ 2018;613-614:1449-59.

[12] Ailstock MS, Norman CM, Bushmann PJ. Common Reed Phragmites australis : Control and Effects Upon Biodiversity in Freshwater Nontidal Wetlands. Restor Ecol 2001;9:49-59.

[13] Coleman H, Levine J. Mechanisms underlying the impacts of exotic annual grasses in a coastal California meadow. Biol Invasions 2007;9:65-71.

[14] Farnsworth E, Meyerson L. Comparative ecophysiology of four wetland plant species along a continuum of invasiveness. Wetlands 2003;23:750-62.

[15] Holdredge C, Bertness M. Litter legacy increases the competitive advantage of invasive Phragmites australis in New England wetlands. Biol Invasions 2011;13:423-33.

[16] Setter T., Ingram K., Tuong T. Environmental characterization requirement for strategic research in rice grown under adverse conditions of drought, flooding, or salinity. Rainfed Lowl Rice Agric Res High-Risk Environ Ed by KT Ingram, IRRI $1995: 3-18$

[17] Verhoeven JTA, Setter TL. Agricultural use of wetlands: opportunities and limitations. Ann Bot 2010;105:155-63.

[18] Pinto E, Almeida A, Ferreira IMPLVO. Essential and non-essential/toxic elements in rice available in the Portuguese and Spanish markets. J Food Compos Anal 2016;48:81-7.

[19] Singh B, Singh V. Fertilizer Management in Rice. In book: Rice Production Worldwide Edition: 1stChapter: 10Publisher: Springer Int Publ AG 2017Editors BS Chauhan, K Jabran, G Mahajan 2017.

[20] Li M, Liu J, Xu Y, et al. Phosphate adsorption on metal oxides and metal hydroxides: A comparative review. Environ Rev 2016;24:319-32.

[21] Correll D. The role of phosphorus in the eutrophication of receiving waters: A review. J Environ Qual 1998;27:261. 
[22] N. Sharpley A, Chapra S, Wedepohl R, et al. Managing Agricultural Phosphorus for Protection of Surface Waters: Issues and Options. J Environ Qual 1994;23.

[23] Maiga Y, von Sperling M, Mihelcic J. Constructed Wetlands. In: J.B. Rose and B. Jiménez-Cisneros, (eds) Global Water Pathogen Project.

http://www.waterpathogens.org (C. Haas, J.R. Mihelcic and M.E. Verbyla) (eds) Part 4 Management Of Risk from Excreta and Wastewater) http://www.waterpathogen 2017.

[24] Hernández-Crespo C, Martín M. Determination of background levels and pollution assessment for seven metals $(\mathrm{Cd}, \mathrm{Cu}, \mathrm{Ni}, \mathrm{Pb}, \mathrm{Zn}, \mathrm{Fe}, \mathrm{Mn})$ in sediments of a Mediterranean coastal lagoon. Catena 2015;133:206-14.

[25] Vymazal J, Březinová T. Accumulation of heavy metals in aboveground biomass of Phragmites australis in horizontal flow constructed wetlands for wastewater treatment: A review. Chem Eng J 2016;290:232-42.

[26] Zhang Y, Song C, Ji L, et al. Cause and effect of N/P ratio decline with eutrophication aggravation in shallow lakes. Sci Total Environ 2018;627:1294-302.

[27] Rai PK. Heavy Metal Pollution in Aquatic Ecosystems and its Phytoremediation using Wetland Plants: An ecosustainable approach. Int J Phytoremediation 2008;10:133-60.

[28] Meuleman AFM, Beekman JHP, Verhoeven JTA. Nutrient retention and nutrientuse efficiency in Phragmites australis stands after wasterwater application. Wetlands 2002;22:712-21.

[29] Važić T, Svirčev Z, Dulic T, et al. Potential for energy production from reed biomass in the Vojvodina region (north Serbia). Renew Sustain Energy Rev $2015 ; 48: 670-80$.

[30] Matsumura Y, Minowa T, Yamamoto H. Amount, availability, and potential use of rice straw (agricultural residue) biomass as an energy resource in Japan. Biomass and Bioenergy 2005;29:347-54.

[31] Kumari M, Tripathi BD. Efficiency of Phragmites australis and Typha latifolia for heavy metal removal from wastewater. Ecotoxicol Environ Saf 2015;112:80-6.

[32] Boluda R, Andreu V, Gilabert MA, et al. Relation between reflectance of rice crop and indices of pollution by heavy metals in soils of albufera natural park (Valencia, Spain). Soil Technol 1993;6:351-63.

[33] Yadav D, Kapur M, Kumar P, et al. Adsorptive removal of phosphate from aqueous solution using rice husk and fruit juice residue. Process Saf Environ Prot 2015;94:402-9.

[34] Ugurlu A, Salman B. Phosphorus removal by fly ash. Environ Int 1998;24(8):9118. 
[35] Abbas MN. Phosphorus removal from wastewater using rice husk and subsequent utilization of the waste residue. Desalin Water Treat 2015;55:970-7.

[36] El-Sobky ESEA. Effect of burned rice straw, phosphorus and nitrogen fertilization on wheat (Triticum aestivum L.). Ann Agric Sci 2017;62:113-20.

[37] Smol M, Kulczycka J, Henclik A, et al. The possible use of sewage sludge ash (SSA) in the construction industry as a way towards a circular economy. J Clean Prod 2015;95:45-54.

[38] Mor S, Chhoden K, Ravindra K. Application of agro-waste rice husk ash for the removal of phosphate from the wastewater. J Clean Prod 2016;129:673-80.

[39] Xu Y, Hao M, Lu C, et al. Effects of micro-environmental climate on the carbonation depth and the $\mathrm{pH}$ value in fly ash concrete. J Clean Prod 2018.

[40] Seliem MK, Komarneni S, Abu Khadra MR. Phosphate removal from solution by composite of MCM-41 silica with rice husk: Kinetic and equilibrium studies.

Microporous Mesoporous Mater 2016;224:51-7.

[41] Ahmaruzzaman M. A review on the utilization of fly ash. Prog Energy Combust Sci 2010;36:327-63.

[42] Tran DV. World rice production: main issues and technical possibilities. In: J. C, editor. Act Rech sur le riz en Clim méditerranéen, vol. 24(2), Montpellier :

CIHEAM; 1997, p. 57-69.

[43] Langmuir I. The constitution and fundamental properties of solids and liquids. Part I. J Am Chem Soc 1916;38:2221-95.

[44] Freundlich H. Über die Adsorption in Lösungen. Zeitschrift Für Phys Chemie $1906 ; 57: 385-470$

[45] Temkin MI. Adsorption Equilibrium and the Kinetics of Processes on Nonhomogeneous Surfaces and in the Interaction between Adsorbed Molecules. Zhurnal Fiz Skoi Khimii 1941;Vol. 15:296-332.

[46] Chen Y, Wang F, Duan L, et al. Tetracycline adsorption onto rice husk ash, an agricultural waste: Its kinetic and thermodynamic studies. J Mol Liq 2016.

[47] Chen Y, Wang F, Duan L, et al. Tetracycline adsorption onto rice husk ash, an agricultural waste: Its kinetic and thermodynamic studies. J Mol Liq 2016;222:487_ 94.

[48] Ma Z, Li Q, Yue Q, et al. Adsorption removal of ammonium and phosphate from water by fertilizer controlled release agent prepared from wheat straw. Chem Eng J 2011;171:1209-17.

[49] Vassileva P, Voikova D. Investigation on natural and pretreated Bulgarian clinoptilolite for ammonium ions removal from aqueous solutions. J Hazard Mater $2009 ; 170: 948-53$. 
[50] Shi ZL, Liu FM, Yao SH. Adsorptive removal of phosphate from aqueous solutions using activated carbon loaded with Fe(III) oxide. Xinxing Tan Cailiao/New Carbon Mater 2011;26:299-306.

[51] Yadav D, Kapur M, Kumar P, et al. Adsorptive removal of phosphate from aqueous solution using rice husk and fruit juice residue. Process Saf Environ Prot 2015.

[52] Wu Y, Li X, Yang Q, et al. Hydrated lanthanum oxide-modified diatomite as highly efficient adsorbent for low-concentration phosphate removal from secondary effluents. J Environ Manage 2019;231:370-9.

[53] Lu SG, Bai SQ, Zhu L, et al. Removal mechanism of phosphate from aqueous solution by fly ash. Fresenius Environ Bull 2009;161(1):95-101.

[54] Vohla C, Kõiv M, Bavor HJ, et al. Filter materials for phosphorus removal from wastewater in treatment wetlands-A review. Ecol Eng 2011;37:70-89.

[55] Xia P, Wang X, Wang X, et al. Struvite crystallization combined adsorption of phosphate and ammonium from aqueous solutions by mesoporous $\mathrm{MgO}$-loaded diatomite. Colloids Surfaces A Physicochem Eng Asp 2016;506:220-7.

[56] Wong A, Navarro EA, Abril AJ. Microalgal oil production for use in rice farms in Albufera (València) region. Int J Green Econ 2013;7:181.

[57] Soria JM. Past, present and future of la Albufera of Valencia Natural Park. Limnetica 2006;25:135-42.

[58] Delivand MK, Barz M, Gheewala SH. Logistics cost analysis of rice straw for biomass power generation in Thailand. Energy 2011;36:1435-41.

[59] Schiemenz K, Eichler-Löbermann B. Biomass ashes and their phosphorus fertilizing effect on different crops. Nutr Cycl Agroecosystems 2010;87:471-82.

[60] Ahmed MJ. Application of raw and activated Phragmites australis as potential adsorbents for wastewater treatments. Ecol Eng 2017;102:262-9. 


\section{Table 1}

Physical and chemical properties of the adsorbent materials.

\begin{tabular}{|c|c|}
\hline Samples & RA \\
\hline $\mathrm{pH}$ & 10.3 \\
\hline BET surface area $/\left(\mathrm{m}^{2} \mathrm{~g}^{-1}\right)$ & 17 \\
\hline External surface area $/(\%)$ & 91 \\
\hline \multicolumn{2}{|l|}{ Composition /(wt. \%) } \\
\hline $\mathrm{Si}$ & 25.99 \\
\hline $\mathrm{Al}$ & 0.49 \\
\hline $\mathrm{Fe}$ & 0.81 \\
\hline Mn & 0.29 \\
\hline $\mathrm{Mg}$ & 3.22 \\
\hline $\mathrm{Ca}$ & 13.07 \\
\hline $\mathrm{Na}$ & 1.04 \\
\hline $\mathrm{K}$ & 6.32 \\
\hline $\mathrm{P}$ & 1.51 \\
\hline $\mathrm{Zn}$ & 0.08 \\
\hline $\mathrm{Cu}$ & 0.01 \\
\hline
\end{tabular}


Table 2

Isotherm models for adsorption of phosphorous at different temperatures.

Table 2.

Models

$\mathrm{T} / \mathrm{K}$

283

Reed

Langmuir

$q_{\max } /\left(\mathrm{mg} \mathrm{g}^{-1}\right)$

18,22

$K_{L} /\left(\mathrm{L} \mathrm{mg}^{-1}\right)$

$\mathrm{R}^{2}$

0,39

0.95

DAIC 0.0

Freundlich

$K_{F}^{*}$

$n$

4,69

0,38

$\mathrm{R}^{2}$

0.77

DAIC

48.5

Tempkin

$B\left(\mathrm{mg} \mathrm{g}^{-1}\right)$

$K_{T}\left(\mathrm{~L} \mathrm{mg}^{-1}\right)$

$\mathrm{R}^{2}$

3,42

4,42

DAIC

0.89

24

293

303

23,15

21,27

0,59

1,53

0.96

0.96

* units of $K_{F}\left(\mathrm{mg}^{1-(1 / \mathrm{n})} \mathrm{L}^{1 / \mathrm{n}} \mathrm{g}^{-1}\right)$

$\begin{array}{ll}9,88 & 11,63 \\ 0,24 & 0,19 \\ 0.89 & 0.81\end{array}$

3,77

12,75

0.94

0,19

3,27

28,18

0.67 


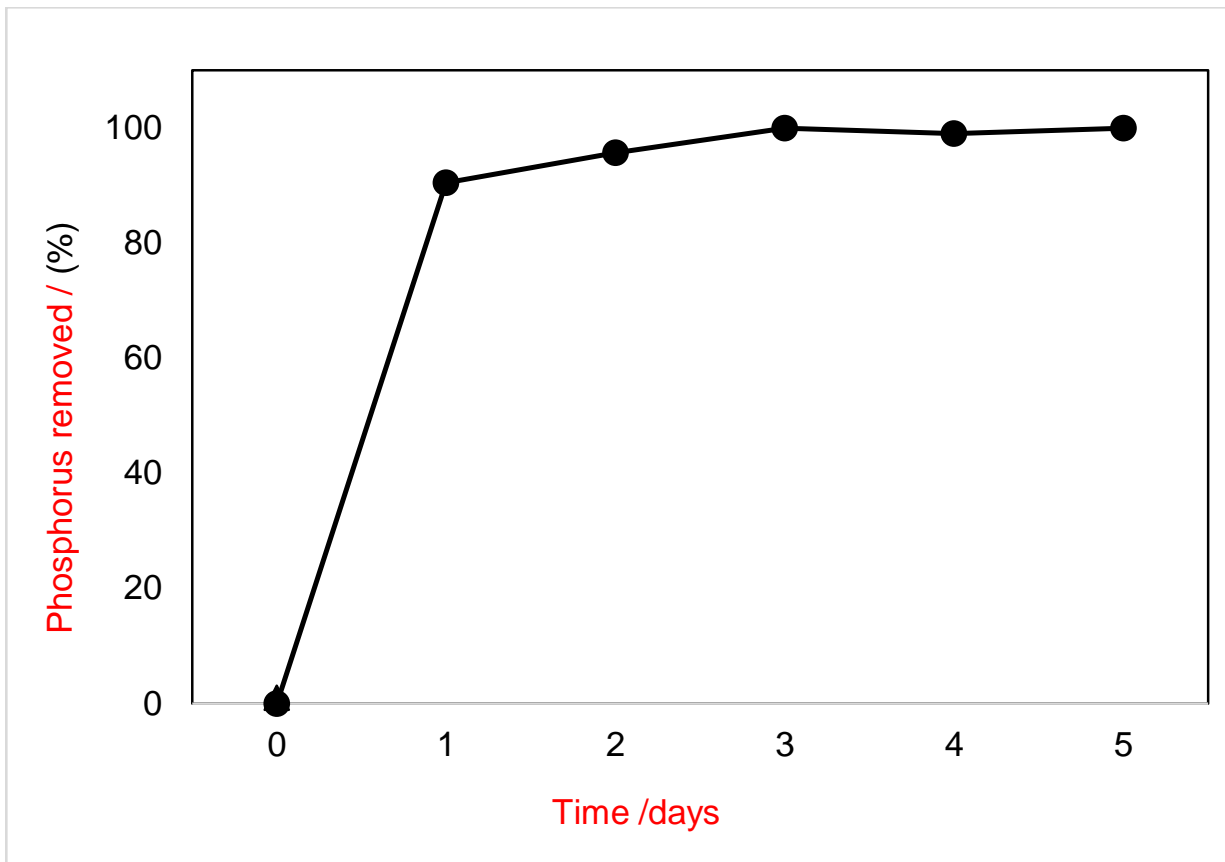

Figure 1: Kinetic of reed ash in conical flask with $1.5 \mathrm{~g} \mathrm{~L}^{-1}$ at $293 \mathrm{~K}$. 


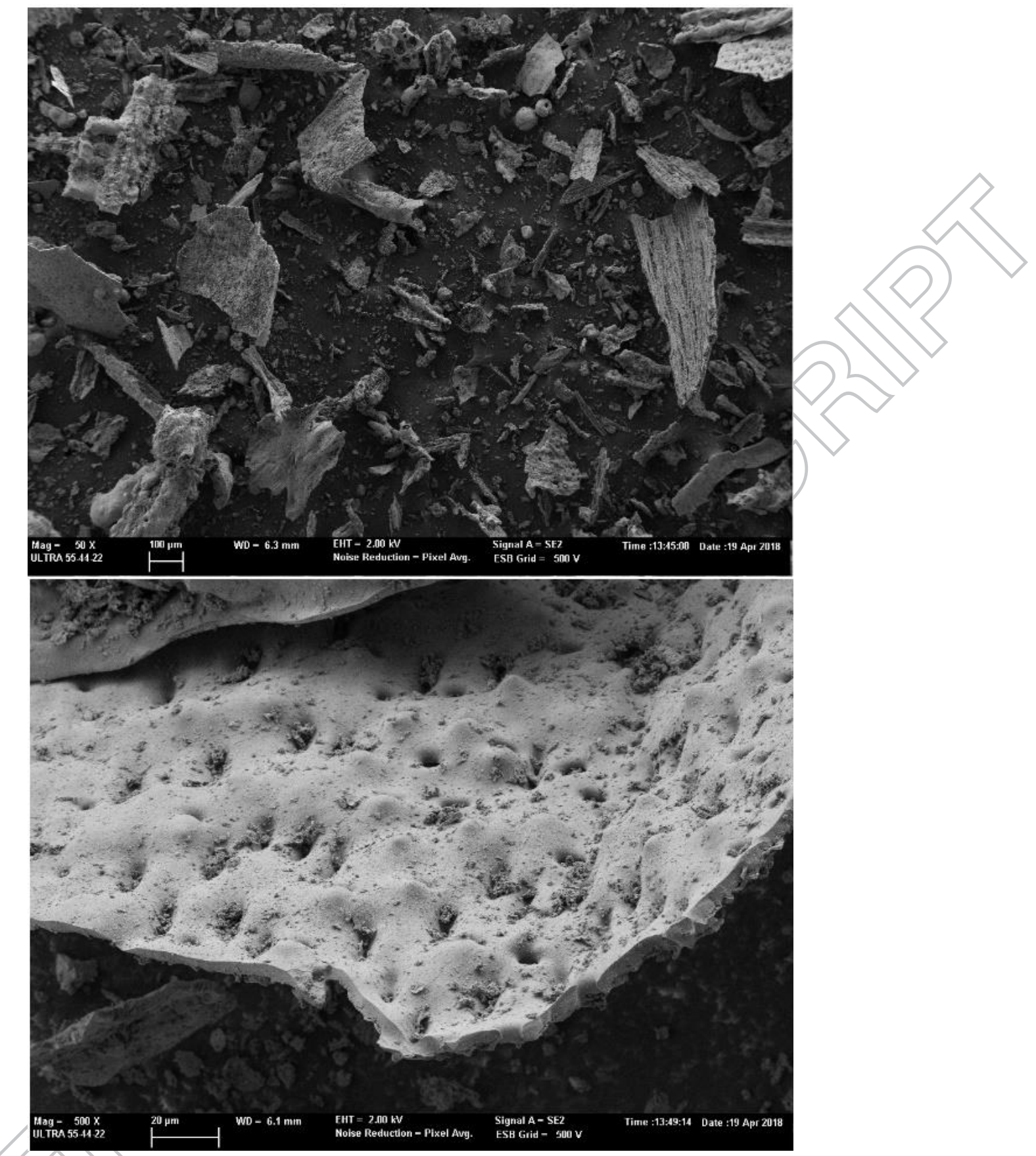

Figure 2: Scanning electron micrograph of reed ash adsorbent.

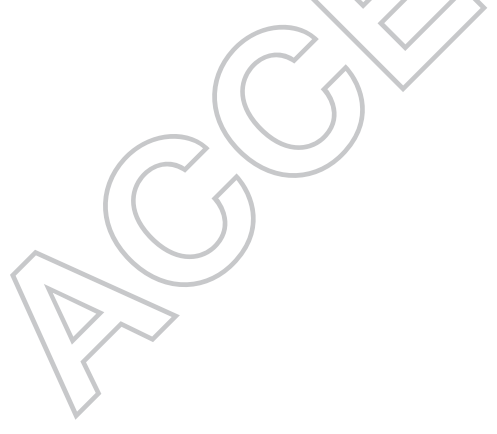




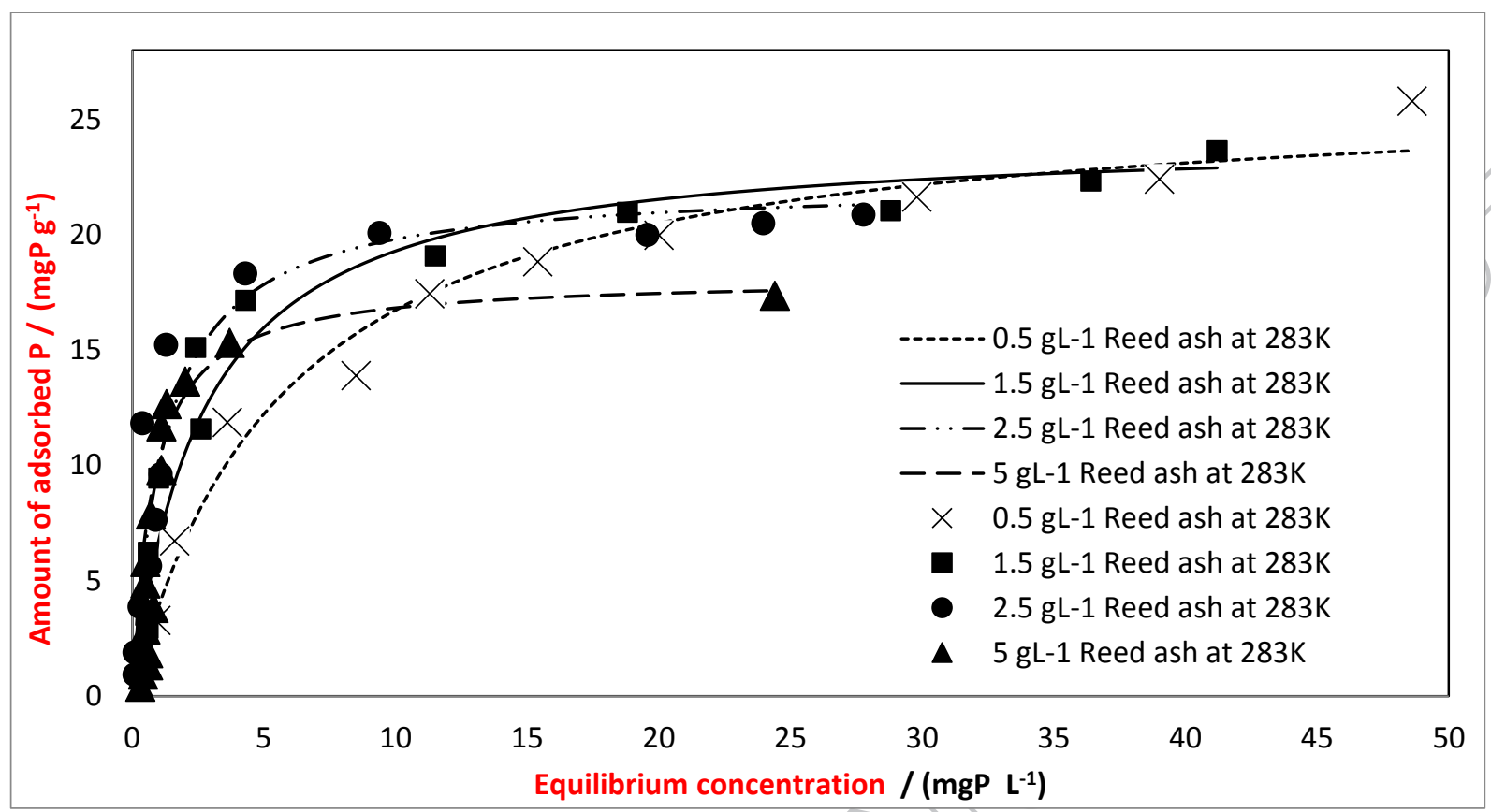

Figure 3: Reed ash in conical flask with $0.5,1.5,2.5$ and $5 \mathrm{~g} \mathrm{~L}^{-1}$ and $2.5,5,7.5,10,15,20,25,30$, $40,50,60,65,70,75,80 \mathrm{ppm}$ of phosphorus, at $293 \mathrm{~K}$. 


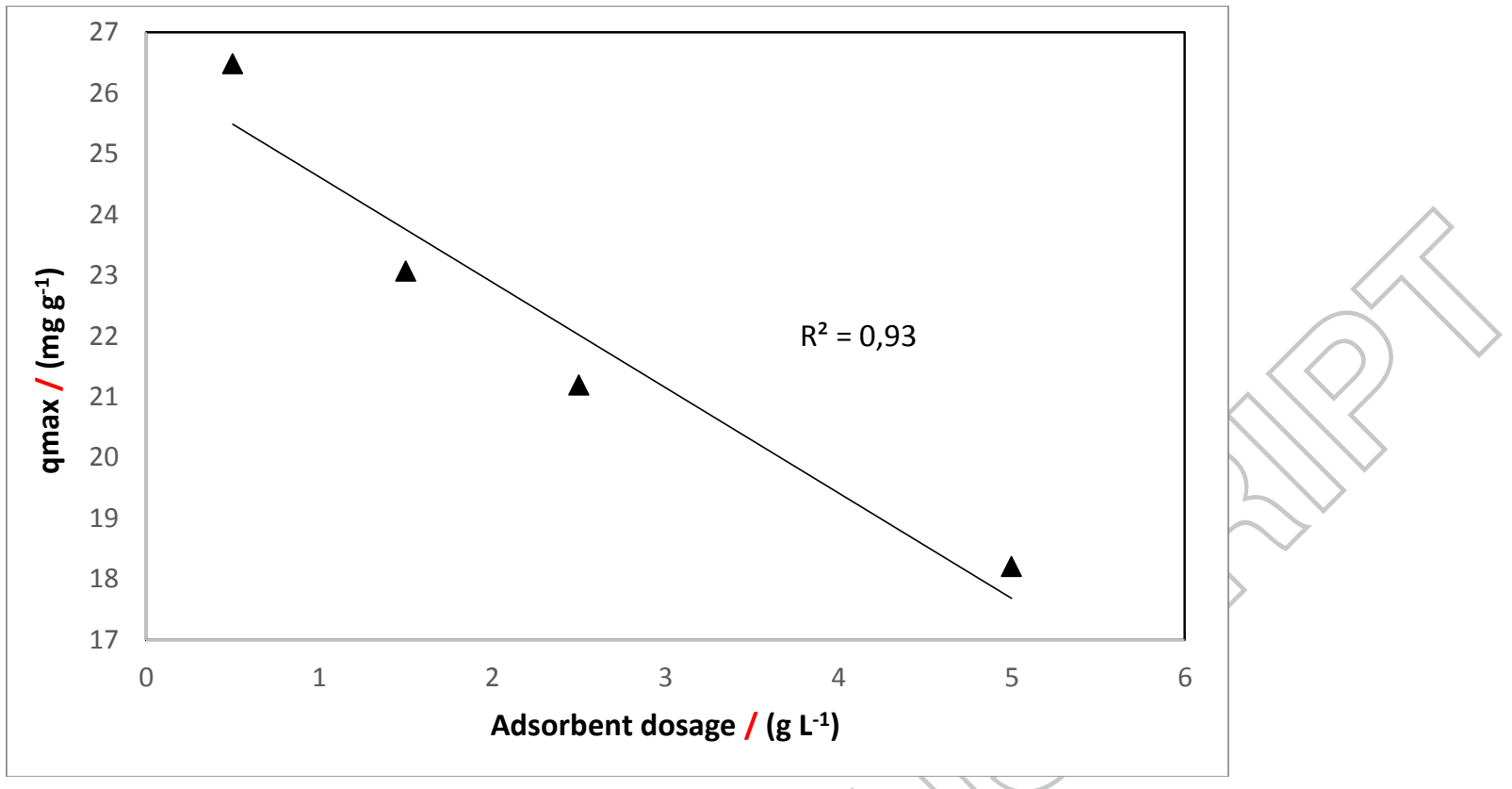

Figure 4: Qmax of reed ash in conical flask with $0.5,1.5,2.5$ and $5 \mathrm{~g} \mathrm{~L}^{-1}$ of reed ash at $293 \mathrm{~K}$. 


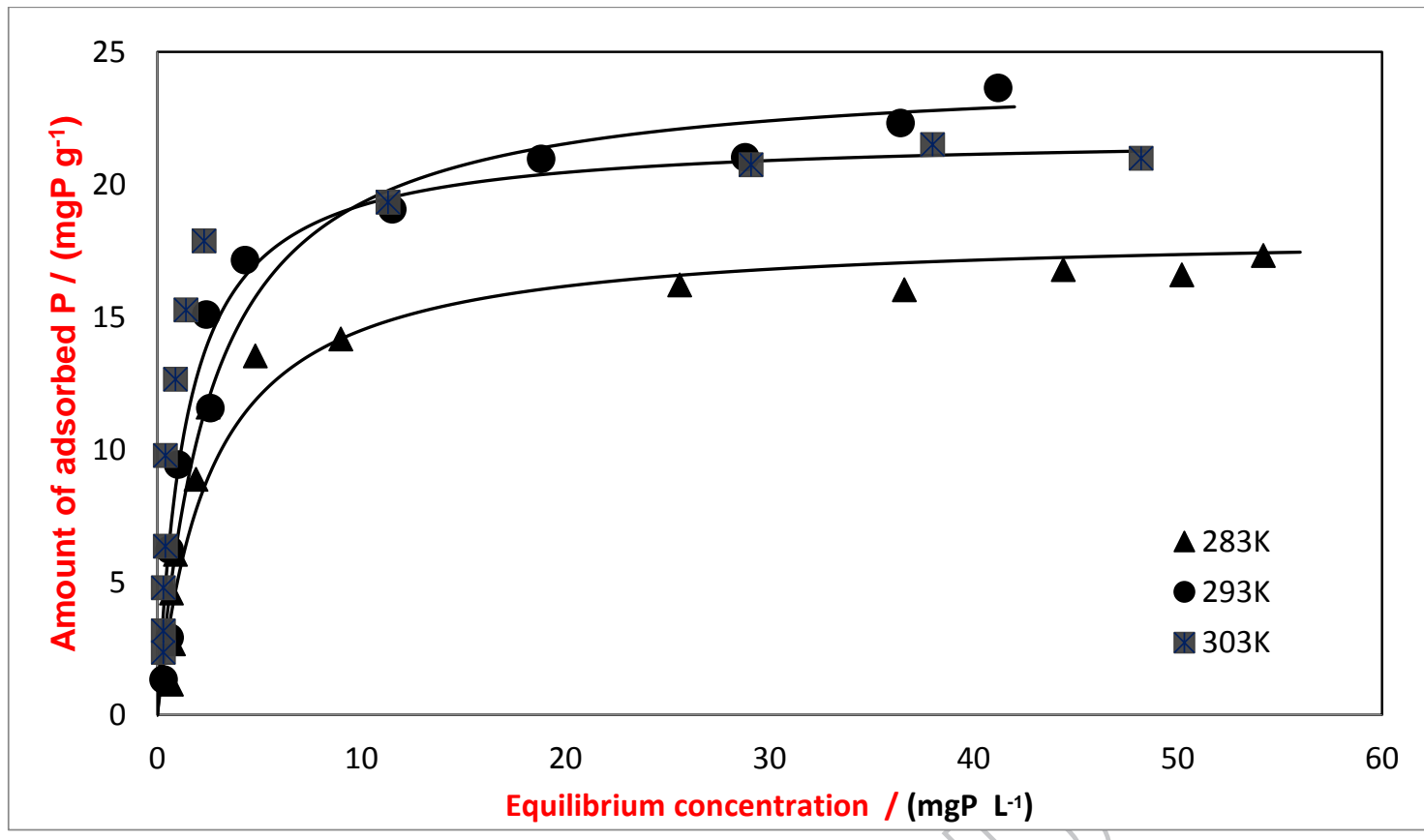

Figure 5: Reed ash in conical flask with $1.5 \mathrm{~g} \mathrm{~L}^{-1}$ and 2.5, 5, 10, 15, 20, 25, 30, 40, 50, 60, 65, 70 and 80 ppm of phosphorus at 283, 293 and $303 \mathrm{~K}$. 

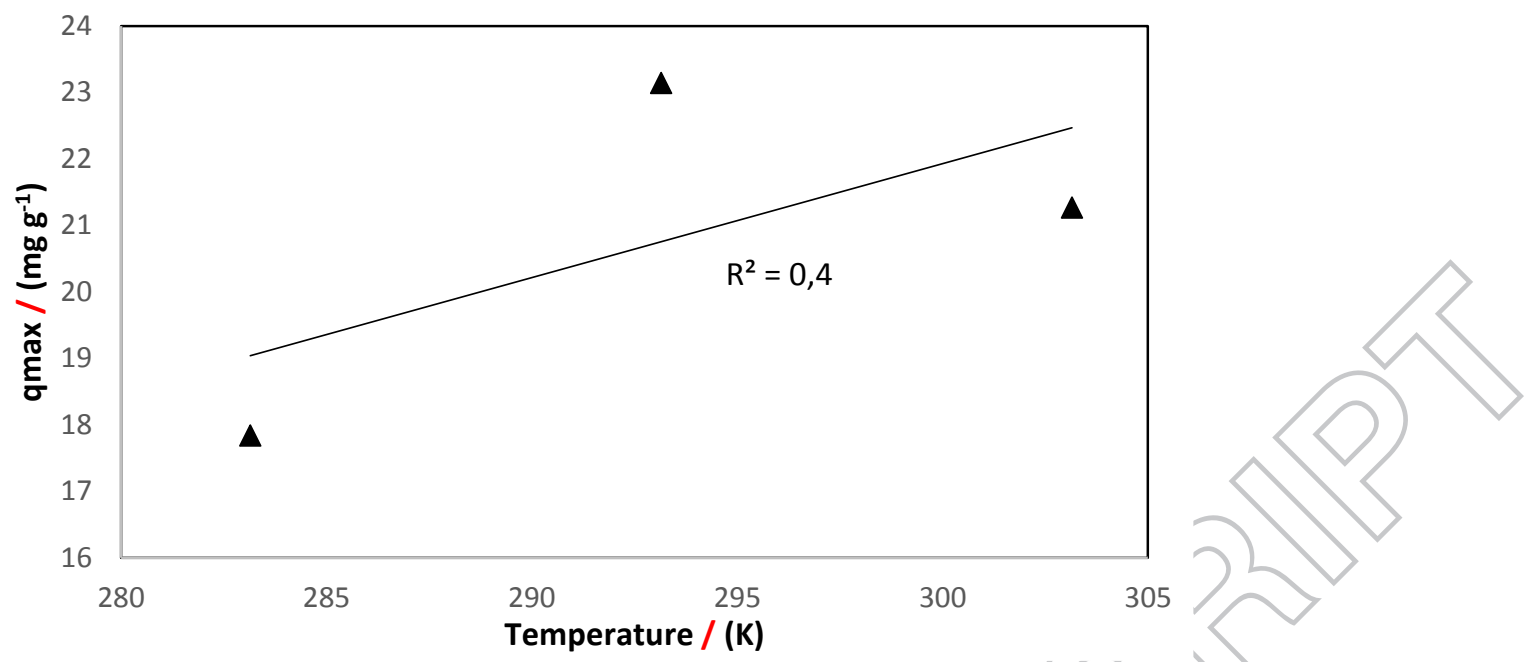

Figure 6: Qmax of Reed ash in conical flask with $1.5 \mathrm{~g} \mathrm{~L}^{-1}$ of reed ash at 283, 293 and $303 \mathrm{~K}$. 


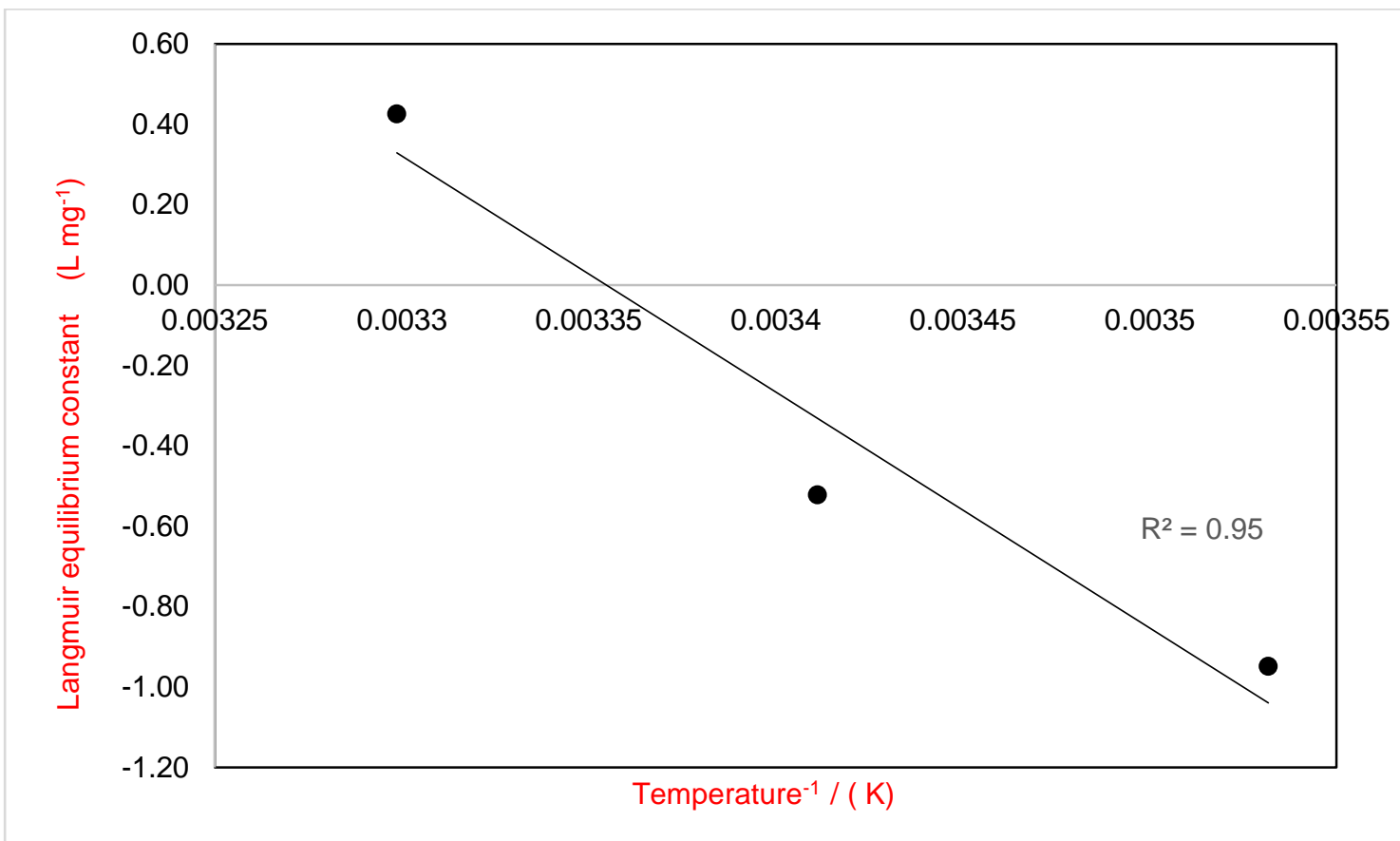

Figure 7: Thermodynamic plot for the adsorption of phosphorus at 1/283, 1/ 293 and 1/303 K. 


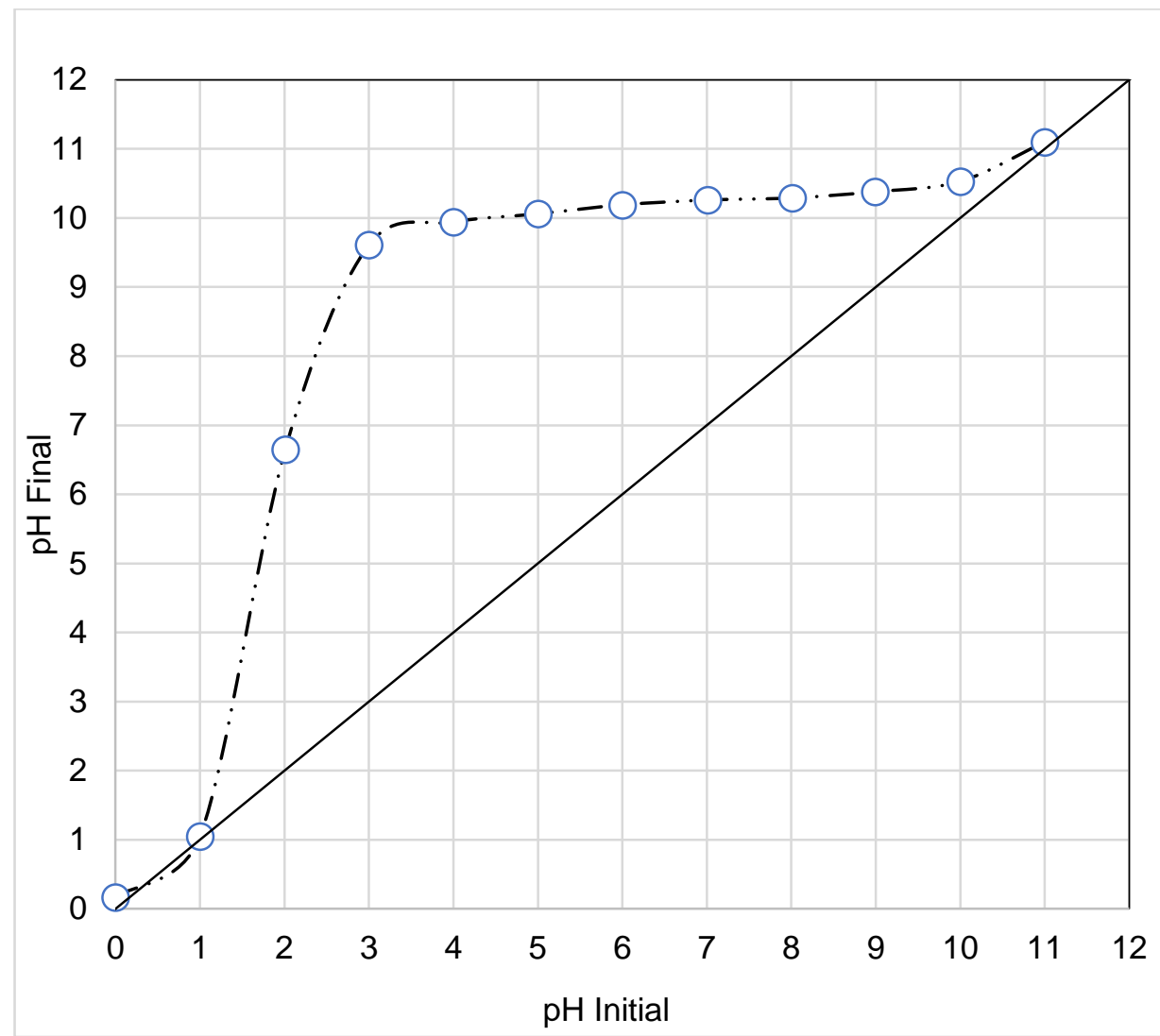

Figure 8: Buffer effect of the ash in the $\mathrm{pH}$ with $1.5 \mathrm{~g} \mathrm{~L}^{-1}$ of reed ash. 


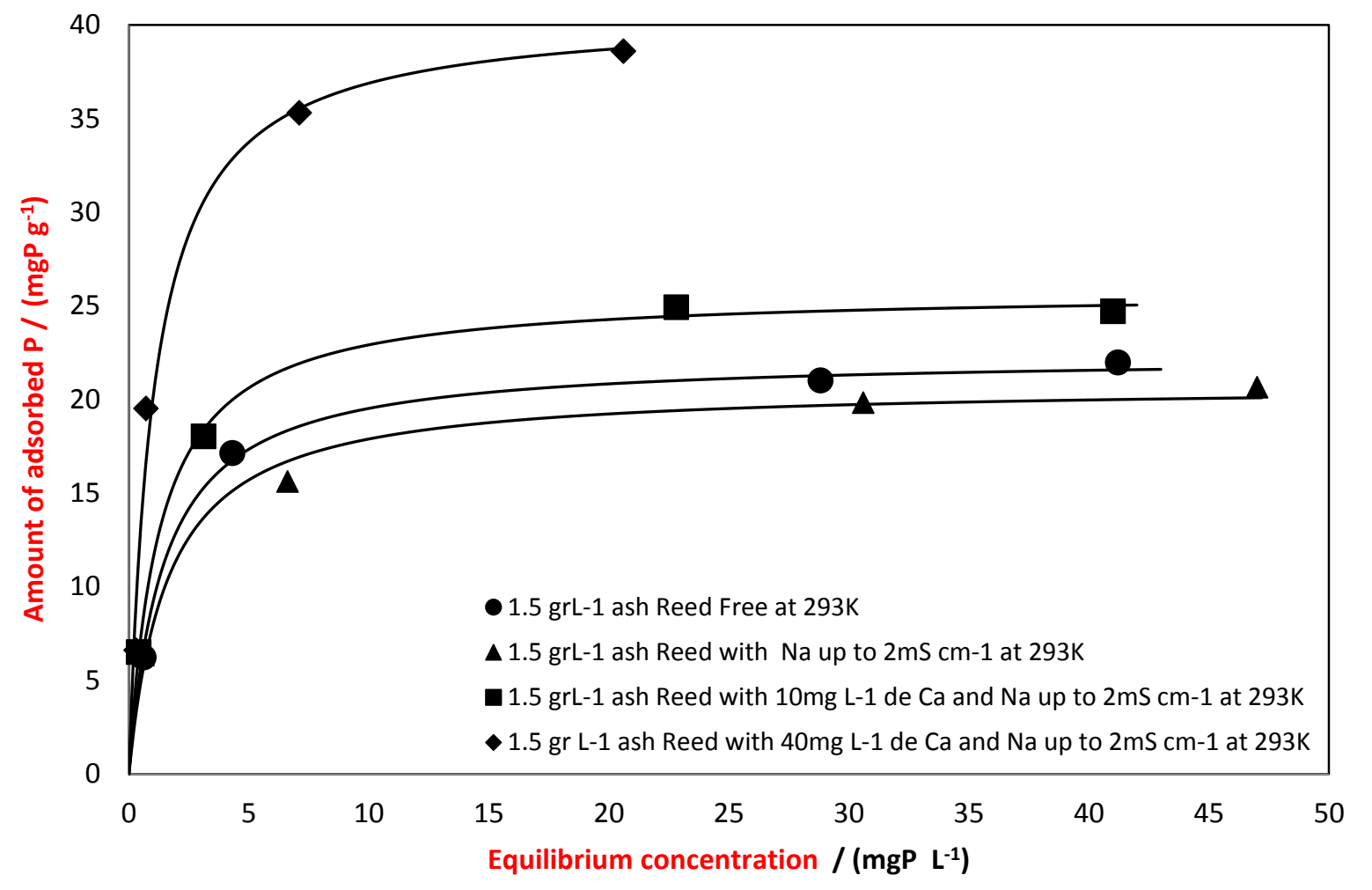

Figure 9: Determination of the point of zero charge for reed ash adsorbent. 


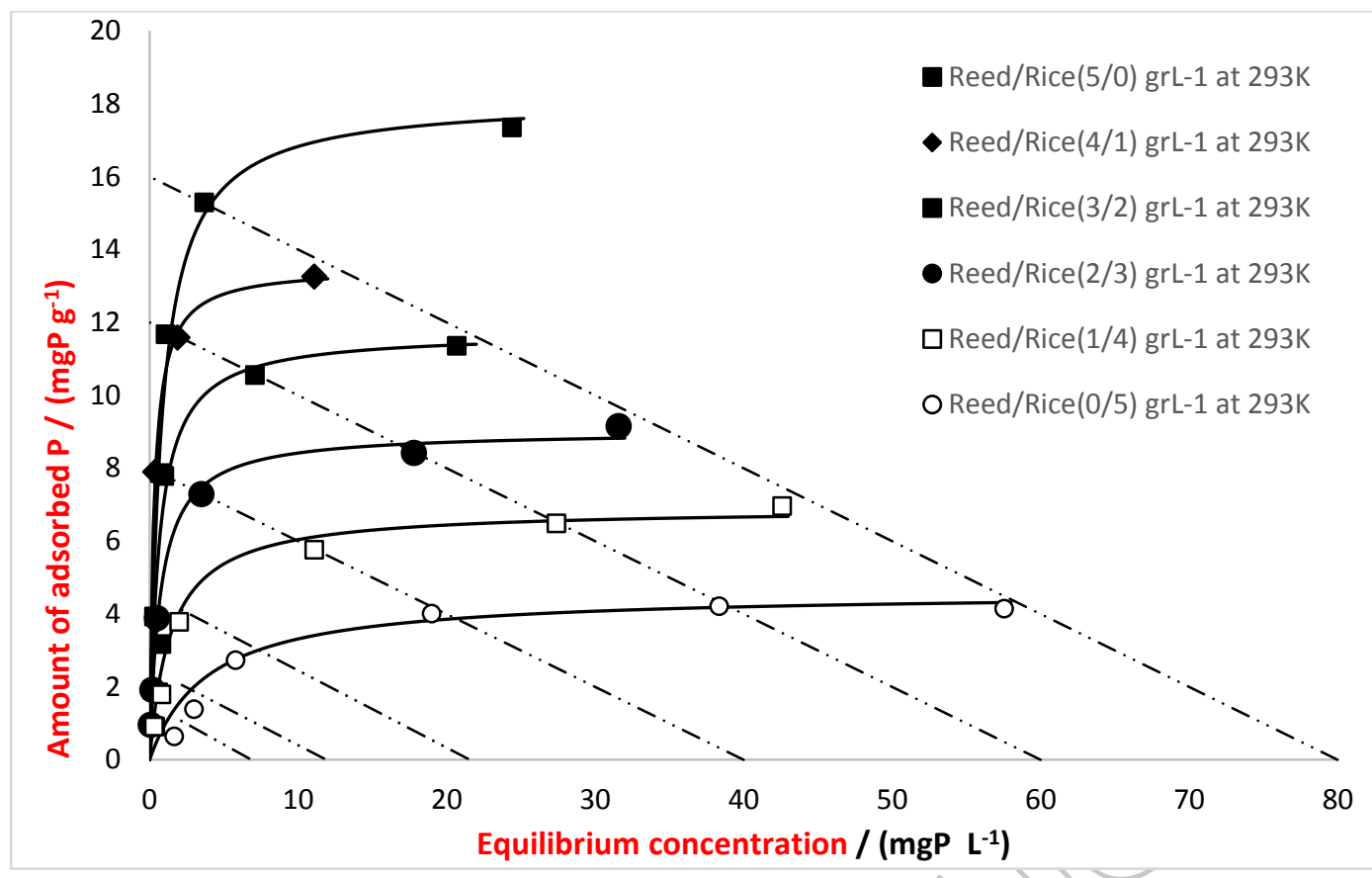

Figure 10: Proportional adsorption mixing rice straw ash and reed ash in conical flask with $5 \mathrm{~g} \mathrm{~L}$ ${ }^{1}$ and 5, 10, 20, 40, 60 and $80 \mathrm{~g} \mathrm{~L}^{-1}$ of phosphorus, at $293 \mathrm{~K}$. On relation between Reed/Rice 5/0, in addition there are $110 \mathrm{~g} \mathrm{~L}^{-1}$ of phosphorus. 
APPENDIX A

Supplementary Material - Supporting Information

\section{FIGURES.}

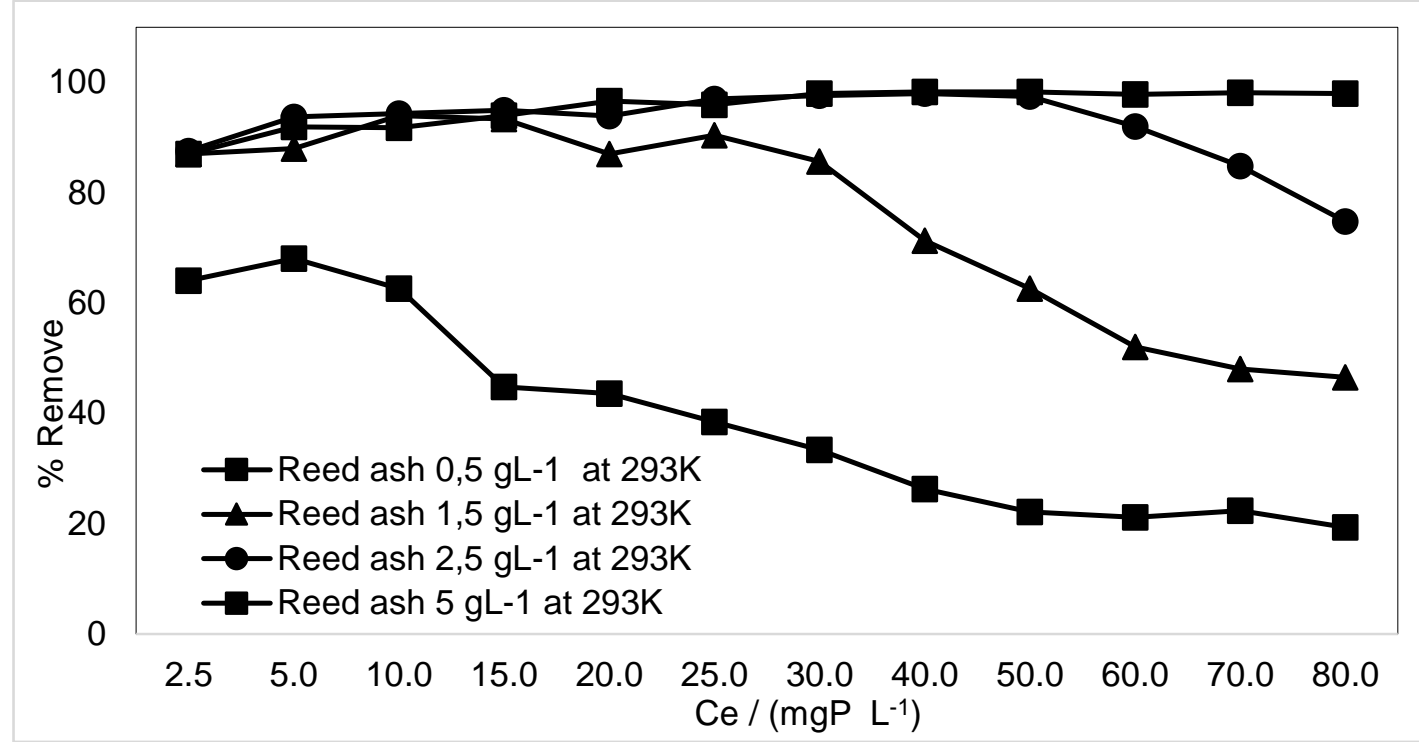

Figure A: \% removal of reed ash in conical flask with $0.5,1.5,2.5$ and $5 \mathrm{~g}^{-1}$ in reed ash and 2.5, 5, $10,15,20,25,30,40,50,60,70,80$ ppm of phosphorous, at $293 \mathrm{~K}$.

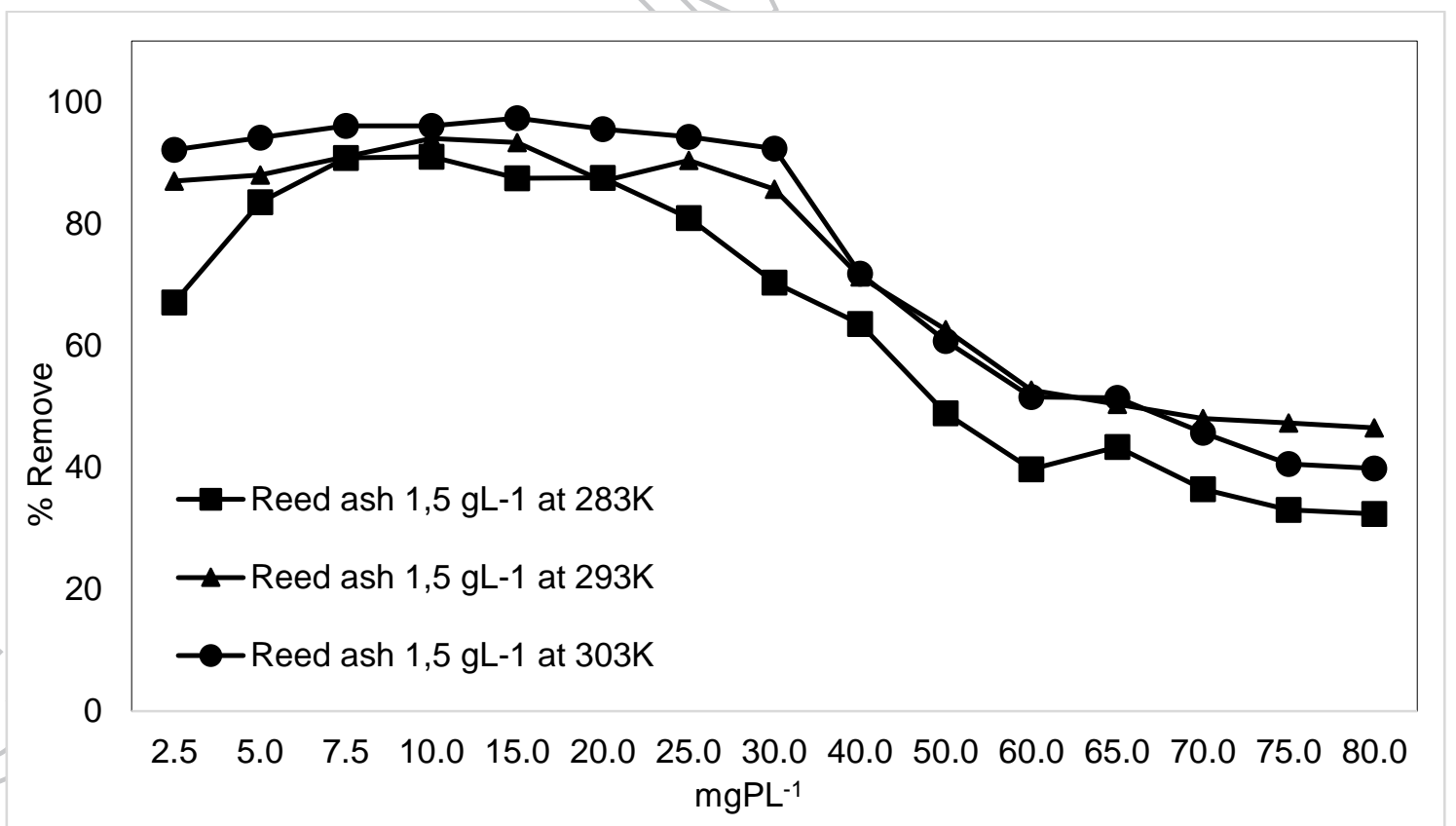

Figure B: \% removal of Reed ash in conical flask with $1.5 \mathrm{~g} \mathrm{l}^{-1}$ and 2.5, 5, 7.5,10, 15, 20, 25, 30, $40,50,60,65,70,75,80 \mathrm{ppm}$ of phosphorous, at 283, 293 and $303 \mathrm{~K}$. 